\title{
Akuntansi Sederhana Bagi Usaha Rumah Tangga Pengolahan Buah Mangrove di Kabupaten Mempawah
}

\section{(Simple Accounting for Household Businesses of Processing Mangrove Fruit in Mempawah District)}

\author{
Dewi Kurniati*, Eva Dolorosa, Nurliza \\ Jurusan Sosial Ekonomi Pertanian, Fakultas Pertanian, Universitas Tanjungpura, Jl.Prof. Dr. Hadari Nawawi No 1, \\ Bansir Laut, Kecamatan Pontianak Tenggara, Kota Pontianak, Kalimantan Barat 78124. \\ *Penulis korespondensi: dewi.kurniati@faperta.untan.ac.id \\ Diterima Agustus 2019/Disetujui Desember 2019
}

\begin{abstract}
ABSTRAK
Buah mangrove bisa dimanfaatkan sebagai bahan makanan alternatif. Bisnis rumah tangga di Kabupaten Mempawah mengolah buah mangrove menjadi produk dalam bentuk dodol, sirup, dan tepung. Namun demikian, pengolahan yang dilakukan oleh masyarakat sangat sederhana dan membutuhkan waktu yang lama. Salah satu kelemahan bisnis rumah tangga dalam mengelola bisnis mereka adalah manajemen keuangan yang buruk, khususnya terkait dengan proses pembukuan akuntansi. Kegiatan pengabdian masyarakat ini bertujuan untuk memberikan pelatihan akuntansi untuk bisnis rumah tangga sehingga mereka dapat memiliki pengetahuan dan prosedur manajemen keuangan yang lebih baik. Metode yang digunakan adalah praktik pelatihan akuntansi. Kegiatan pelatihan ini diikuti oleh para pelaku bisnis rumah tangga pengolahan buah mangrove yang dilakukan di Desa Sungai Bakau Besar Laut, Kecamatan Sungai Pinyuh, Kabupaten Mempawah. Hasil pelatihan menunjukkan peningkatan dalam pengetahuan dan kemampuan peserta dalam pembukuan akuntansi dan peserta berlatih sendiri dalam bisnis masing-masing. Untuk mendukung keberlanjutan program pelatihan ini, diperlukan program pendampingan dari pemerintah dan akademisi.
\end{abstract}

Kata kunci: akuntansi, pengolahan buah mangrove, usaha rumah tangga

\begin{abstract}
Mangrove fruits can be used as an alternative food stuffs. Household businesses in Mempawah Regency processed mangrove fruits into products in the form of dodol, syrup, and flour. Nevertheless, the processing done by the community was very simple and required a long time. One disadvantage of household businesses in managing their businesses was the poor financial management, specifically related to the accounting bookkeeping process. This service activity aimed to provide accounting training for household businesses so that they can have better financial management knowledge and procedures. The method used was the accounting training practice. This training activity was participated in by the mangrove fruit processing household business operators which was carried out in Sungai Bakau Besar Laut Village, Siliki Pinyuh Subdistrict, Mempawah District. The results of the training showed an increase in the knowledge and abilities of the participants in accounting bookeeping and the participants practiced themselves in their respective businesses. To support the sustainability of this training program, a mentoring program from the government and academia are needed.
\end{abstract}

Keywords: accounting, household businesses, processing of mangrove fruits

\section{PENDAHULUAN}

Kalimantan Barat memiliki hutan mangrove seluas 149.344,19 ha (Hartini et al. 2010). Ekosistem hutan mangrove tersebut tersebar pada tujuh kabupaten/kota pesisir yang ada di Kalimantan Barat, antara lain Kabupaten Kubu Raya, Mempawah, Bengkayang, Sambas, Ketapang, dan Kota Singkawang. Salah satu manfaat dengan adanya pelestarian hutan mangrove adalah mencegah abrasi (pengikisan tanah akibat air laut), menghasilkan oksigen, sebagai tempat tinggal bagi tumbuhan dan hewan kecil (seperti kepiting, kerang, ikan-ikan kecil, dan spesies primate yang tinggal di dahan mangrove itu), serta manfaat lainnya. Selain itu, tanaman mangrove juga dapat menjadi penyedia kebutuhan pangan. Bagi masyarakat sekitar 
mangrove juga dapat dimanfaatkan sebagai bahan makanan, yaitu bagian buahnya yang sering disebut buah mangrove.

Kumpulan pepohonan yang tumbuh dalam hutan mangrove terdiri dari jenis tanaman yang buah dan daunnya dapat dikonsumsi oleh manusia maupun hewan, namun ada pula yang tidak dikonsumsi. Potensi lain dari mangrove sebagai sumber makanan belum banyak diteliti dan dikembangkan. Padahal terdapat hasil mangrove yang dapat menjadi sumber pangan yang mengandung karbohidrat yang bersumber dari hutan mangrove, yaitu buah mangrove. Upaya pemanfaatan dari beberapa bagian jenis mangrove untuk dijadikan produk makanan yang bermanfaat (Sahil \& Soamole 2013). Produk makanan dari mangrove tersebut diharapkan menjadi alternatif atau sumber pendapatan tambahan bagi masyarakat di sekitar ekosistem mangrove. Beberapa jenis tanaman mangrove potensial yang dapat diolah menjadi bahan pangan adalah Avicennia, Bruguiera, dan Sonneratia.

Daerah Kabupaten Mempawah yang termasuk daerah pesisir memiliki kawasan hutan mangrove cukup luas di mana terdapat ketersediaan buah mangrove yang cukup melimpah. Kelompok ibu-ibu rumah tangga yang berada di sekitar kawasan mangrove Kabupaten Mempawah memanfaatkan buah mangrove dengan melakukan pengolahan sederhana menjadi produk olahan pangan seperti dodol, sirup, dan tepung mangrove. Hasil olahan tersebut bertujuan untuk dijual kembali untuk menambah pendapatan keluarga. Bagi kelompok ibu-ibu cukup mudah mendapatkan buah mangrove tanpa mengeluarkan biaya yang besar. Umumnya biaya yang dikeluarkan terkait dengan pembelian peralatan, tenaga kerja, dan bahan baku pendukung lainnya seperti tepung, gula, dan mentega. Aktivitas pembelian bahan baku dan peralatan tidak pernah tercatat secara tertib. Proses pembukuan akuntansi tidak dilakukan dengan teratur dan baik. Demikian pula dengan penerimaan hasil penjualan yang diperoleh tidak pernah tercatat dalam pembukuan secara tertib, sehingga tidak teridentifikasi perolehan laba yang didapat dari penjualan usaha produk olahan buah mangrove. Menurut Savitri \& Saifudin (2018) terdapat usaha mikro kecil menengah tidak melakukan kegiatan pencatatan akuntansi. Catatan yang dibuat masih sangat sederhana, yaitu hanya terkait dengan pembelian bahan baku serta sebagian biaya yang mereka keluarkan saja, sehingga sangat sulit untuk mengetahui seberapa besar biaya keseluruhan yang dibutuhkan dalam sekali produksi, dan menentukan laba usaha.

Pengelolaan keuangan menjadi faktor kelemahan pada usaha pengolahan buah mangrove yang dilakukan kelompok ibu-ibu rumah tangga. Pelaku usaha cenderung mengabaikan pentingnya melakukan pencatatan akuntansi usahanya, sehingga penggunaan modal usaha bercampur dengan modal untuk kebutuhan rumah tangga lainnya (Suranta \& Sudaryono 2015). Hal ini tentu berdampak pada keberhasilan usaha karena terdapat hubungan antara perilaku akuntansi rumah tangga dengan keberhasilan usaha rumah tangga (Rant et al. 2017). Masalah utamanya adalah belum adanya kesadaran dan motivasi untuk melakukan pencatatan akuntansi usaha karena minimnya pengetahuan tentang akuntansi, cenderung mengabaikan pentingnya melakukan pencatatan akuntansi. Kurangnya motivasi berakibat pada efektivitas penerapan pembukuan pada usaha rumah tangga (Octavia et al. 2016; Yulianti 2016; Nurliza et al. 2019). Hal ini berakibat pada sistem keuangan usaha yang tidak dapat membedakan antara keuntungan usaha dan kas pribadi.

Kurangnya pemahaman dari kelompok ibuibu rumah tangga terhadap laporan keuangan karena seluruh ibu-ibu yang melakukan pengolahan buah mangrove tidak memiliki kompetensi di bidang akuntansi. Laba real yang diperoleh dari penjualan menjadi tidak teridentifikasi untuk menambah modal dan kebutuhan rumah tangga. Melihat kenyataan tersebut maka diperlukan upaya dalam bentuk kegiatan pelatihan pembukuan akuntansi untuk diberikan kepada pelaku usaha kelompok ibu-ibu rumah tangga pengolahan produk buah mangrove. Kegiatan pelatihan dapat meningkatkan pengetahuan dan keterampilan pembukuan dari pelaku usaha (Nurliza et al. 2019). Tujuan kegiatan pelatihan pembukuan akuntansi sederhana ini adalah meningkatkan kesadaran pelaku usaha rumah tangga produk olahan buah mangrove akan penting melakukan pencatatan dan penerapan akuntansi serta memberikan pengetahuan kepada pelaku usaha rumah tangga mengenai pembukuan akuntansi sederhana pada kegiatan usaha rumah tangga pengolahan buah mangrove.

\section{METODE PELAKSANAAN KEGIATAN}

Kegiatan pengabdian dilakukan di Desa Sungai Bakau Besar Laut, Kecamatan Sungai 
Pinyuh, Kabupaten Mempawah, Kalimantan Barat. Metode pada kegiatan pengabdian ini adalah melakukan pelatihan. Pelatihan dilakukan pada kelompok ibu-ibu rumah tangga yang bertempat tinggal di kawasan mangrove yang melakukan usaha pengolahan buah mangrove. Pemecahan masalah dilakukan dalam bentuk kegiatan sosialisasi, pelatihan, dan evaluasi kepada pelaku usaha rumah tangga pengolahan buah mangrove tentang pembukuan akuntansi secara sederhana. Materi yang disampaikan tersebut terdiri atas penjelasan secara lisan mengenai pentingnya melakukan pencatatan dan penerapan akuntansi untuk suatu usaha, manfaat membuat pembukuan akuntansi usaha, mengidentifikasi jenis biaya, macam-macam jenis penerapan akuntansi yang terdiri atas neraca dan laporan rugi laba, perbedaan masing-masing bentuk pembukuan akuntansi, format penyusunan, dan cara perhitungan pembukuan akuntansi usaha.

Materi juga diberikan dalam bentuk tulisan yang berisi tentang konsep dan manfaat pembukuan akuntansi usaha, macam-macam jenis pembukuan akuntansi usaha dan perhitungan masing-masing bentuk pembukuan akuntansi, kemudian diperbanyak untuk dibagikan kepada masing-masing peserta pelatihan. Selain materi berbentuk tulisan, peralatan menulis seperti pulpen, pensil, penggaris, penghapus, dan buku keuangan juga dibagikan kepada masing-masing peserta pelatihan. Fasilitas kegiatan pelatihan lainnya berupa laptop, infocus, kertas HVS, papan tulis white board beserta spidol, dan penghapus. Evaluasi dilakukan dengan pre-test dan post-test melalui kuesioner dan wawancara mengenai pengetahuan dan penerapan akuntansi usaha.

\section{HASIL DAN PEMBAHASAN}

Kegiatan pertama yang dilakukan oleh tim pelatih adalah melakukan evaluasi awal terhadap para peserta untuk mengetahui tingkat pemahaman dan pengetahuan peserta tentang arti pembukuan akuntansi usaha, manfaat dari pembuatan pembukuan, jenis-jenis pembukuan akuntansi, penyusunan format, dan cara perhitungan pembukuan usaha. Kegiatan ini dilakukan dengan menyebarkan kuesioner yang berisi pertanyaan mengenai pengertian dan manfaat pembukuan akuntansi, pengalaman pelatihan yang pernah diikuti, pengetahuan tentang jenis-jenis pembukuan akuntansi, dan lain sebagainya. Kuesioner yang disebar kepada para peserta harus dijawab dalam waktu kurang lebih 30 menit.

Hasil dari evaluasi awal menunjukkan bahwa seluruh peserta belum ada yang pernah mendapatkan pelatihan tentang pembukuan akuntansi usaha. Sebagian peserta atau 50\% peserta memiliki sedikit pengetahuan tentang pengertian dan manfaat pembukuan akuntansi. Sebanyak $25 \%$ peserta tidak memiliki pengetahuan tentang pengertian dan manfaat pembukuan dan hanya sebanyak $25 \%$ peserta termasuk cukup memiliki pengetahuan tentang pengertian dan manfaat pembukuan akuntansi. Sebanyak $75 \%$ peserta tidak memiliki pengetahuan tentang jenis-jenis pembukuan akuntansi dan cara membuat pembukuan. Hanya sebanyak $8 \%$ peserta saja yang cukup memiliki pengetahuan. Sementara itu sebanyak 17\% peserta sedikit mengetahui jenis-jenis pembukuan akuntansi dan cara membuat pembukuan. Evaluasi awal ini menunjukkan bahwa pengetahuan kelompok ibu-ibu sebagai peserta pelatihan belum cukup baik dan perlu dilakukan suatu kegiatan pelatihan yang dapat meningkatkan pemahaman kelompok ibu-ibu tersebut mengenai pembuatan pembukuan akuntansi.

Kemudian tim pelatih menyampaikan materi pelatihan secara lisan dengan metode ceramah di hadapan seluruh peserta pelatihan memaparkan dan menjelaskan pengertian pembukuan akuntansi, manfaat menyusun pembukuan akuntansi, memaparkan jenis biaya yang dikeluarkan pada kegiatan usaha, menjelaskan macam-macam bentuk pembukuan akuntansi yang terdiri atas neraca dan laporan rugi, laba, serta perbedaan masing-masing bentuk pembukuan tersebut. Tahapan yang dilakukan dalam melakukan pembukuan akuntansi sederhana usaha rumah tangga pengolahan buah mangrove meliputi: 1) Memisahkan antara pengeluaran dan pemasukan pribadi dengan pengeluaran dan pemasukan usaha; 2) Mempersiapkan dokumen pendukung seperti kuitansi, nota penjualan, dan tagihan (invoice); 3) Mempersiapkan buku pencatatan/ melakukan pembukuan, yaitu pencatatan transaksi keuangan secara kronologis (menurut urutan waktu) dan sistematik (menurut caracara pembukuan) meliputi pencatatan kas/uang kas keluar masuk; dan 4) Membuat laporan keuangan sederhana minimal terdiri atas neraca dan laporan rugi laba.

Adapun prinsip pembukuan akuntansi yang harus diperhatikan oleh pelaku usaha rumah tangga adalah: 1) Buku kas terdiri dari kolom: 
tanggal, keterangan, jumlah uang masuk, dan jumlah uang keluar; 2) Pencatatan dilakukan menurut urut-urutan waktu/urutan tanggal (kronologis); 3) Memberikan informasi yang jelas seperti tanggal penerimaan atau pembayaran dan jumlah yang jelas; 4) Semua catatan yang dibuat dapat dipertanggungjawabkan, semua yang dicatat dalam format buku kas adalah kejadian yang nyata telah terjadi dan ada buktinya (misalnya pembelian ada bukti nota pembelian); dan 5) Kegiatan yang dicatat diukur dengan uang (dalam nilai rupiah).

Menyusun laporan neraca terdiri atas: aktiva (meliputi kas, piutang, dan persediaan) dan pasiva (meliputi hutang dan modal akhir). Pada penyusunan laporan rugi laba terdiri atas aktivitas perusahaan berupa penjualan dan biaya-biaya yang terjadi. Laporan rugi laba memuat secara terinci mengenai pendapatan dan biaya. Perhitungan biaya-biaya produksi meliputi biaya bahan baku langsung + biaya tenaga kerja langsung + biaya produksi tidak langsung (biaya bahan pelengkap/pembantu) $=$ total biaya produksi. Sementara itu perhitungan biaya non produksi seperti biaya pemasaran.

Kendala yang ditemui pada kegiatan pelatihan ini adalah seluruh peserta pelatihan tidak memiliki dasar pengetahuan akuntansi, terutama penggunaan istilah-istilah dalam akuntansi yang masih asing bagi peserta, sehingga dampaknya selama pelatihan seluruh peserta bingung dan tidak memahami apa yang disampaikan oleh tim pelatih. Peserta tidak terbiasa untuk memisahkan antara informasi keuangan pribadi dan keuangan usaha, sehingga tidak ada dokumen pencatatan yang teratur. Hal ini berdampak pada kemampuan peserta menyelesaikan cara perhitungan dan pengelompokan biaya. Pada setiap materi yang disampaikan terjadi dialog tanya jawab, di mana peserta menyampaikan pertanyaan yang belum dipahami (Gambar 1). Diskusi yang terjadi berlangsung aktif, di mana peserta sangat antusias terhadap setiap materi yang disampaikan dan dikaitkan dengan masalah yang dijumpai dalam kehidupan sehari-hari. Tim pelatih menyimak dan mencatat setiap pertanyaan peserta serta langsung menanggapi dan memberi solusi yang tepat atas permasalahan yang dihadapi peserta.

Selanjutnya, tim pelatih menyampaikan materi pelatihan secara lisan mengenai format penyusunan dan cara perhitungan pembukuan akuntansi usaha. Tim pelatih langsung memberikan contoh kasus perhitungan dan penyusunan pembukuan akuntansi untuk lebih memudahkan pemahaman para peserta pelatihan. Tahap selanjutnya para peserta diminta untuk praktik pelatihan langsung membuat pembukuan akuntansi untuk usahanya (Gambar 2), dengan menggunakan peralatan praktik yang telah dibagikan, yaitu buku keuangan, pulpen, pensil, penggaris, dan kertas HVS. Masing-masing peserta dibantu oleh tim pelatihan dalam menyusun pembukuan akuntansi, mulai dari mengidentifikasi biaya-biaya yang dikeluarkan selama proses usaha berlangsung, mencatat hasil produksi dan besarnya hasil penjualan yang diperoleh, kemudian memasukkan data informasi biaya tersebut ke dalam buku keuangan pada kolom debit atau kredit.

Setelah penyampaian materi pelatihan dengan metode ceramah dan praktik pembuatan pembukuan akuntansi, selanjutnya dilakukan evaluasi kembali tentang pemahaman peserta terhadap materi yang telah diberikan dengan mengajukan kuesioner berisi daftar pertanyaan untuk mengetahui sampai sejauh mana pemahaman peserta terhadap materi pelatihan yang telah diberikan. Peserta harus menjawab daftar pertanyaan tersebut dalam waktu kurang lebih 30 menit. Gambar 3 menunjukkan evaluasi kegiatan pelatihan pembukuan dengan kuesioner.

Hasil evaluasi menunjukkan seluruh peserta memahami dengan baik materi yang diberikan dan terjadi peningkatan pengetahuan pada pe-

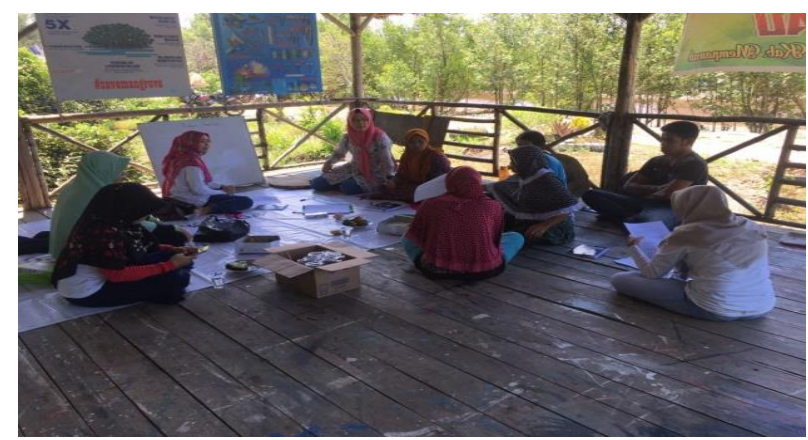

Gambar 1 Diskusi tanya jawab peserta terhadap materi pelatihan.

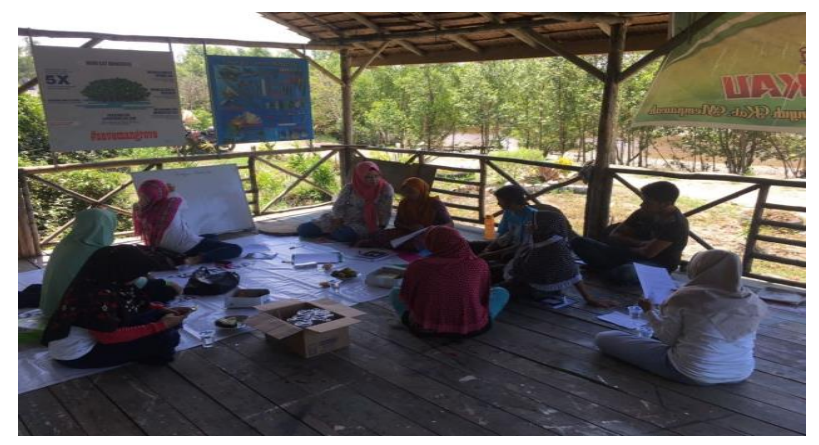

Gambar 2 Praktik pelatihan pembukuan. 


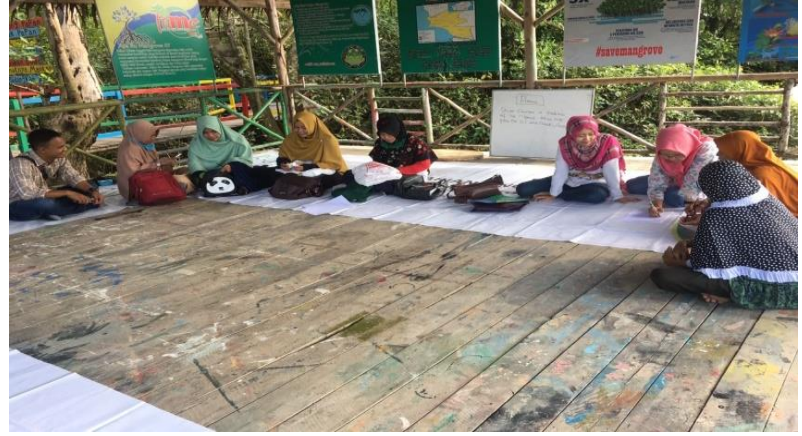

Gambar 3 Evaluasi kegiatan pelatihan pembukuan dengan kuesioner.

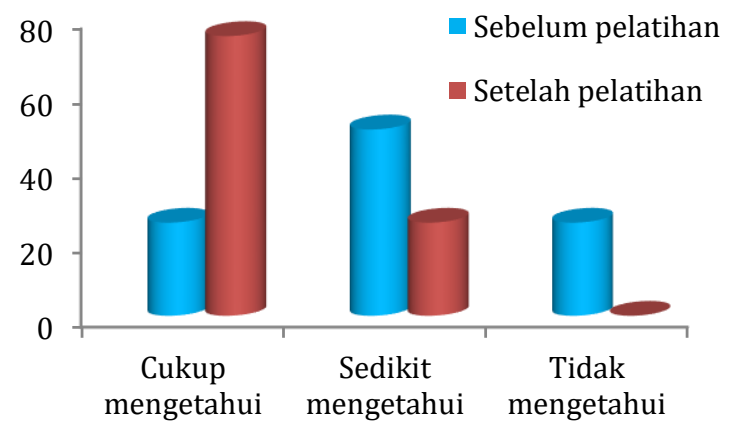

Gambar 4 Hasil evaluasi peserta pelatihan tentang pengetahuan arti dan manfaat pembukuan.

serta pelatihan seperti terlihat pada Gambar 4 . Terjadinya peningkatan atas pemahaman pembukuan akuntansi dari pelaku usaha mikro menunjukkan bahwa kegiatan pelatihan efektif untuk diberikan (Hapsari et al. 2017; Nurliza et al. 2019). Pada Gambar 4 ditunjukkan bahwa setelah disampaikan materi pelatihan terjadi peningkatan pengetahuan peserta tentang arti dan manfaat pembukuan akuntansi. Sebelum pelatihan dilaksanakan sebesar $50 \%$ peserta sedikit mengetahui tentang arti dan manfaat pembukuan akuntansi. Setelah dilakukan pelatihan, sebanyak $75 \%$ peserta memiliki cukup pengetahuan tentang arti dan manfaat pembukuan akuntansi. Hal ini menunjukkan sebagian peserta dapat memahami setiap materi yang disampaikan dan dapat mengikuti praktik pembuatan pembukuan akuntansi dengan baik.

Hasil evaluasi peserta pelatihan tentang pengetahuan jenis-jenis pembukuan akuntansi terlihat pada Gambar 5. Evaluasi menunjukkan setelah mengikuti pelatihan, pengetahuan peserta cukup mengetahui tentang pengetahuan jenis-jenis pembukuan akuntansi yang umumnya digunakan oleh suatu perusahaan atau pelaku usaha, yaitu menunjukkan peningkatan menjadi seanyak $42 \%$ peserta. Sebelum pelatihan di-

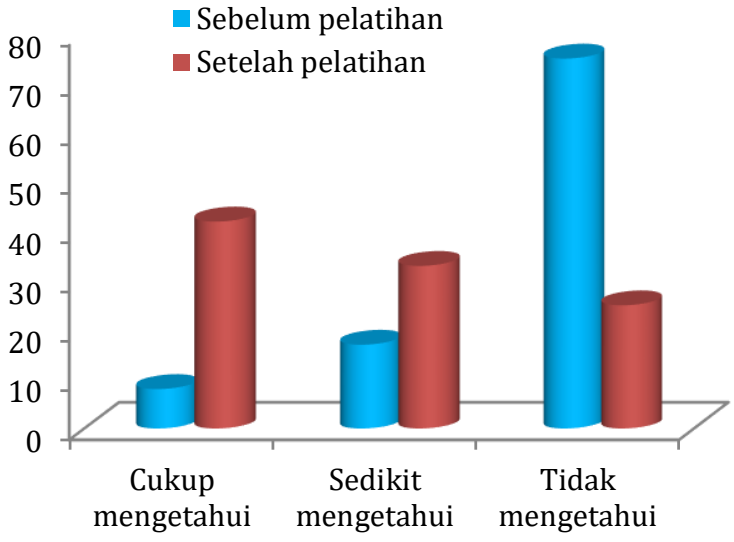

Gambar 5 Hasil evaluasi peserta pelatihan tentang pengetahuan jenis-jenis pembukuan akuntansi.

lakukan, jumlah peserta yang tidak mengetahui tentang jenis-jenis pembukuan yang digunakan pada suatu usaha adalah sebesar $75 \%$.

Hasil evaluasi peserta pelatihan tentang pengetahuan cara pembuatan pembukuan akuntansi ditunjukkan pada Gambar 6. Pengetahuan peserta pelatihan tentang cara pembuatan pembukuan akuntansi juga mengalami peningkatan dari sebesar $8 \%$ menjadi $33 \%$ peserta yang cukup memiliki pengetahuan cara pembuatan pembukuan, sementara itu jumlah peserta yang tidak memiliki pengetahuan mengalami penurunan dari sebesar $75 \%$ menjadi $17 \%$ peserta. Berdasarkan hasil evaluasi menunjukkan adanya peningkatan dari hasil kegiatan pelatihan pembukuan rumah tangga yang pada akhirnya akan banyak memberikan manfaat bagi pihak pelaku usaha rumah tangga, yaitu sebagai perencana dan pengambil keputusan jangka panjang (Manurung \& Sinton 2013; Hartono et al. 2019), mengetahui keuntungan kerugian yang diperoleh dari setiap periode usaha, evaluasi perkembangan usaha lebih akurat, pelaku usaha lebih percaya diri, dan menjadi pribadi yang hemat serta lebih berhati-hati dalam mengambil keputusan (Mulyani 2018).

Setelah evaluasi pascamateri pelatihan diberikan, peserta diminta untuk membuat pembukuan akuntansi sendiri untuk periode satu bulan ke depan, terutama penyusunan pembukuan untuk usaha pengolahan buah mangrove yang telah dijalani. Selanjutnya, tim pelatih memberitahukan bahwa satu bulan ke depan tim akan meninjau untuk melihat perkembangan hasil pembukuan akuntansi yang dikerjakan oleh peserta. Hasilnya menunjukkan bahwa kelompok 


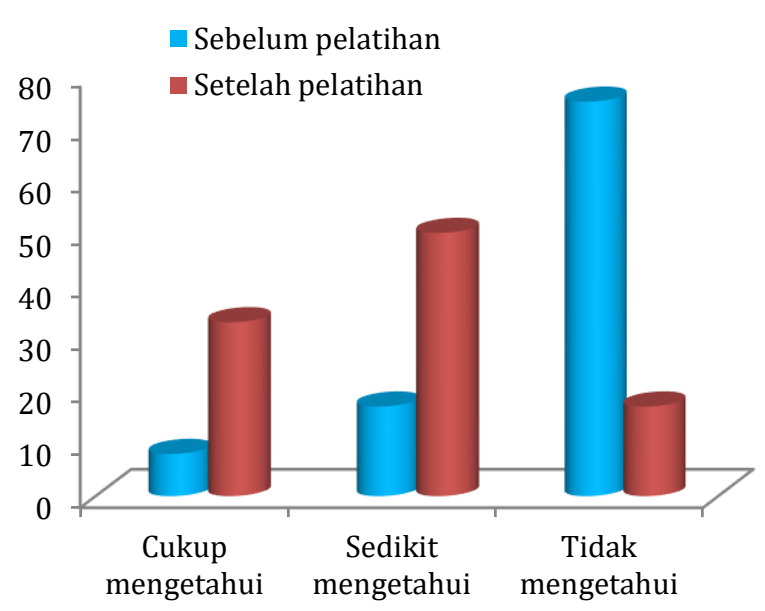

Gambar 6 Hasil evaluasi peserta pelatihan tentang pengetahuan cara pembuatan pembukuan akuntansi.

ibu-ibu memiliki semangat dan keinginan untuk membuat pembukuan secara mandiri, hal ini ditunjukkan dari laporan pembukuan akuntansi yang telah disusun sudah cukup baik.

\section{SIMPULAN}

Kesimpulan yang diperoleh dari kegiatan ini adalah terjadi peningkatan pengetahuan para peserta melalui kegiatan pelatihan pembuatan pembukuan akuntansi dapat meningkatkan wawasan dan pengetahuan kepada para peserta pelatihan tentang penyusunan pembukuan. Peserta pelatihan sangat antusias dan memberikan respons yang sangat baik atas kegiatan pelatihan. Sikap tersebut dapat terlihat selama kegiatan pelatihan berlangsung dari awal hingga akhir kegiatan selesai. Peserta termotivasi mempraktikkan sendiri pada usaha masingmasing. Kegiatan pelatihan ini memberikan peningkatan wawasan dan kemampuan bagi pelaku usaha rumah tangga dalam menerapkan akuntansi bagi usahanya. Oleh karena itu, agar hasil dari kegiatan pelatihan ini dapat berjalan dan ditingkatkan maka diperlukan metode pendampingan dari pihak pemerintah maupun akademisi untuk mendukung keberlanjutan program pelatihan ini.

\section{UCAPAN TERIMA KASIH}

Ucapan terima kasih tim penulis sampaikan kepada Fakultas Pertanian UNTAN melalui dana
DIPA Universitas Tanjungpura sesuai Surat Perjanjian Pelaksanaan Penelitian Nomor: 1073/UN22.3/PP/2018, 5 Maret 2018 yang telah memberi dukungan keuangan terhadap kegiatan PKM ini.

\section{DAFTAR PUSTAKA}

Hapsari DP, Andari, Hasanah AN. 2017. Model Pembukuan Sederhana Bagi Usaha Mikro di Kecamatan Keramatwatu Kabupaten Serang. Jurnal Akuntansi. 4(2): 36-47.

Hartini S, Guridno B, Yulianto M, Suprajaka. 2010. Assesing The Used of remotely Data for Mapping Mangrove Indonesia. Selected topic for remote sensing in $6^{\text {th }}$ WSEAS International Confrence on remote sensing (Remote 10). Iwate Prefectural University. Japan (JP).

Hartono Y, Oklima AM, Wartiningsih A. 2019. Pemberdayaan dan Pengolahan Produk Durian di Desa Juru Mapin Kecamatan Buer Kabupaten Sumbawa. Agrokreatif. Jurnal Ilmiah Pengabdian kepada Masyarakat. 5(2): 115-122.

https://doi.org/10.29244/agrokreatif.5.2.11 5-122

Manurung DTH, Sinton J. 2013. Urgensi Peran Akuntansi dalam Rumah Tangga (Studi Fenomenologis pada Dosen-Dosen Akuntansi di Universitas Widyatama Bandung). Jurnal Ilmiah Akuntansi dan Humanika Jinah. 3(1): 892-911.

Mulyani S. 2018. Penting akuntansi Rumah Tangga Dalam Meningkatkan Hidup Islami. Jurnal Ekonomi Syariah: Equilibrium. 6(2): 206-216.

https://doi.org/10.21043/equilibrium.v6i2.3 707

Nurliza, Dolorosa E, Kurniati D, Hutajulu JH. 2019. Pelatihan Farm Record dan Evaluasi Resiko Usahatani Untuk Peningkatan Kompetensi Petani Mandiri. Dinamisia-Jurnal Pengabdian Kepada Masyarakat. 3(1): 1-7. https://doi.org/10.31849/dinamisia.v3i1.27 20

Octavia A, Sumarni E, Sam I. 2016. Pelatihan Kewirausahaan Dan Manajemen Bagi Ibu Rumah Tangga, Remaja Putri dan Kelompok Usaha Bersama Mutiara Kota Jambi. Jurnal Pengabdian Pada Masyarakat. 31(3): 36-41. 
Rant D, Horvat R, Tominc P, Korosec B. 2016. Household Accounting: A Case of Subsidised Self-Employed Entreprenuers In Slovenia. Naše gospodarstvo/Our Economy. 63(2): 3241. https://doi.org/10.1515/ngoe-20170010

Sahil J, Soamole I. 2013. Pemanfaatan Buah Mangrove Sebagai Sumber Makanan Alternative di Halmahera Barat Maluku Utara. Jurnal Ilmiah Biologi: Biogenesis. 1(2): 91-96. https://doi.org/10.24252/bio.v1i2.453

Savitri RV, Saifudin. 2018. Pencatatan Akuntansi Pada Usaha Mikro Kecil dan Menengah (Studi
Pada UMKM MR. PELANGI Semarang). Jurnal Manajemen Bisnis dan Inovasi. 5(2): 117-125. https://doi.org/10.35794/jmbi.v5i2.20808

Suranta S, Sudaryono EA. 2015. Pengelolaan Keuangan dan Pembukuan Untuk Usaha Kecil Usaha Karak Lele di Sukoharjo. Jurnal Kewirausahaan dan Bisnis. 17(9): 1-16.

Yulianti M. 2016. Akuntansi Dalam Rumah Tangga : Study Fenomenologi Pada Akuntan dan Non Akuntan. Jurnal Akuntansi dan Manajemen. 11(2): 62-75. 